\title{
Revision of Cirratulus (Cirratulidae: Polychaeta) from Argentina, with the description of three new species and a key to identify all species of the area
}

\author{
M. Andrea Saracho-Bottero ${ }^{1}$, M. Lourdes Jaubet ${ }^{1}$, Griselda V. Garaffo ${ }^{1}$ \& Rodolfo Elías ${ }^{1}$ \\ 1. Instituto de Investigaciones Marinas y Costeras, (IIMYC), Facultad de Ciencias Exactas y Naturales (FCEYN), \\ Universidad Nacional de Mar del Plata (UNMdP)- Consejo Nacional de Investigaciones Científicas y Técnicas \\ (CONICET).CC1260.7600 Mar del Plata, Argentina, asaracho@mdp.edu.ar
}

$$
\text { Recibido 03-XII-2018. Corregido 25-V-2019. Accepted 30-VI-2019. }
$$

\begin{abstract}
Introduction: The taxonomy of Cirratulidae is not easy due to the diagnostic characters currently accepted change through ontogeny, in some cases, there are even difficulties to separate juveniles from adults. Among the Cirratulus species cited, described and considered as valid for Argentina are Cirratulus jucundus (Kinberg, 1866), Cirratulus patagonicus (Kinberg, 1866) and Cirratulus mianzanii Saracho Bottero, Elías \& Magalhães, 2017. Objetive: This study made a revision of Cirratulus includes material deposited in the Museo de Ciencias Naturales de La Plata (MLP) and specimens collected privately by J.M. Orensanz that was donated to the laboratory of Bioindicadores Bentónicos of the National University of Mar del Plata. Methods: The specimens were examined with optical equipment (microscope and stereomicroscope) and also by a scanning electron microscope (SEM). Results: A complete examination of the material, revealed a higher number of species than those already mentioned. In the present work, three new species are described from the intertidal and subtidal areas of the Argentine continental shelf: Cirratulus orensanzii n. sp.; Cirratulus knipovichana $\mathbf{n}$. sp. and Cirratulus alfonsinae n. sp. Conclusions: The knowledge about the taxonomy of the family as well as the updating of the geographic registries contributes to the biodiversity of the region, which is of great importance to carry out both ecological studies and conservation plans.
\end{abstract}

Key words: Cirratulus; geographical distribution; taxonomy; new register.

Saracho-Bottero, M. A., Jaubet, M. L., Garaffo, G. V., \& Elías, R. (2019). Revision of Cirratulus (Cirratulidae: Polychaeta) from Argentina, with the description of three new species and a key to identify all species of the area. Revista de Biología Tropical, 67(S5) Suplemento, S169-S182.

The taxonomy of Cirratulidae is not easy due to the diagnostic characters currently accepted change through ontogeny, in some cases, there are even difficulties to separate juveniles from adults. According to Blake (1996), the cirratulids who have groups of tentacular filaments (multitentaculates) instead of paired dorsal tentacles are organized into four genera: Cirratulus Lamarck, 1818, Timarete Kinberg, 1866, Cirriformia Hartman, 1936, and Protocirrineris Czerniavsky,
1881. Posteriorly another genus Fauvelicirratulus Çinar and Petersen, 2011 was added. These genera are distinguished on the basis of the kind(s) chaetae present, the segment(s) from which the tentacular filaments arise, segment(s) from which the branchiae arise, the position of the branchiae and shape of the prostomium. Cirratulus, Timarete and Cirriformia have a more or less wedge-shaped prostomium, capillary chaetae and acicular spines (aciculars). Fauvelicirratulus has a bluntly conical 
to wedge-shaped prostomium, long capillary chaetae and presence of long, straight spines instead of the short acicular ones. Protocirrineris has a bluntly conical to wedge-shaped prostomium and only capillary chaetae.

The genus Cirratulus has almost 38 species currently reported worldwide (Blake \& Magalhães, 2017). Among the species cited, described and valid for Argentina are Cirratulus jucundus (Kinberg, 1866), Cirratulus patagonicus (Kinberg, 1866) and Cirratulus mianzanii Saracho-Bottero, Elías, \& Magalhães, 2017.

As part of a recent revision of the material deposited in national collections, and private collections, a higher number of species than those already mentioned have been registered in Argentina. In the present work, we described three new species: Cirratulus orensanzii n. sp. is a species inhabiting intertidal salt-marshes in the patagonic subantarctic region, while Cirratulus knipovichana $\mathrm{n}$. $\mathrm{sp}$. is widely distributed in subtidal areas of the warm temperate continental shelf, including Uruguay. The last one, Cirratulus alfonsinae $\mathrm{n}$. sp. is only known for the type locality among mussels on a centric beach of Mar del Plata city.

The new species are described and compared with its closest congeners. An illustrated key for the species of Cirratulus from Argentina is presented.

\section{MATERIALS AND METHODS}

This revision of Cirratulus includes material deposited in the Museo de Ciencias Naturales de La Plata (MLP) and specimens collected privately by J.M. Orensanz that was donated to the laboratory of Bioindicadores Bentónicos of the National University of Mar del Plata. The specimens were examined with optical equipment (microscope and stereomicroscope) and also by a scanning electron microscope (SEM) JEOL, JSM-6460 LV. The material for SEM was prepared performing dehydration in ethyl alcohol (70, 80, 90, 95 and $100 \%)$. Samples were dried in HMDS (hexamethyldisilazane), mounted on aluminium stubs and metalized with $\mathrm{Au}-\mathrm{Pd}$.
Type materials of the three newly described species are deposited in the Invertebrate collection of the Museo de Ciencias Naturales de La Plata (MLP), Argentina. Zoobank link: LSIDurn:1sid:zoobank.org:pub:03AECCCDCE01-48C4-A431-280584EAF90C

Additionally, in order to help ecologists to identify Cirratulus species from the area, a key with illustrations have been made.

\section{RESULTS}

SYSTEMATICS

Family CIRRATULIDAE Ryckholt, 1851

Genus Cirratulus Lamarck, 1818

Type Species: Lumbricus cirratus Müller, 1776 accepted as Cirratulus cirratus (O. F. Müller, 1776) (type by monotypy)

Diagnosis (modified after Blake \& Magalhães, 2017): Prostomium wedge-shaped, elongate or blunt, usually with transverse rows of eyespots, with a pair of small slits or depressions nuchal organ at the postero-lateral edge; peristomium with two-three annulations. Two or more grooved tentacular filaments arising from between peristomium and first chaetiger or in a single anterior segment. The first pair of branchiae is found in the same chaetiger that the tentacular filaments, occurring singly, and continuing over most of the body to posterior end, above notopodium or becoming more dorsal in middle body segments. Parapodial rami well separated. Chaetae include capillaries with serrated or smooth edges and curved acicular spines. Pygidium with or without lobes surrounding anus.

Remarks: Taxonomic problems with the genus Cirratulus include the incorrect determinations of Cirratulus cirratus (O. F. Müller, 1776) from widespread areas. Upon a comprehensive study of Cirratulus from various parts of the world, it was seen that it consisted of multiple species. Blake (1996) evaluated records of Cirratulus cirratus and others in the NE Pacific and was able to separate five 
species, one new, none of which agreed with species he had seen from the North Atlantic. He hypothesized a great diversity in Cirratulus species in the world. In the SW Atlantic, a similar pattern can be seen. Cirratulus jucundus (Kinberg, 1866) and Cirratulus patagonicus (Kinberg, 1866) were cited for Argentina from the analysis of material deposited in collections by Saracho Bottero et al. (2017). Cirratulus mianzanii Saracho Bottero, Elías \& Magalhães, 2017 was described for Argentina from the analysis of material collected in Peninsula Valdez, Argentina. Specimens of Cirratulus of numerous areas from Argentina that was collected and identified by Jose M. Orensanz as a complex Cirratulus near cirratus are being currently evaluated and part of the result are presented in this publication.

\section{Cirratulus orensanzii n. sp. Saracho-Bottero \& Elías}

(Fig. 1A-F; Fig. 4D)

Type material: Holotype: complete adult, $20 \mathrm{~mm}$ long, $3 \mathrm{~mm}$ wide for 84 chaetigers (MLP-Oi 2536-1). SW Atlantic Ocean, Argentina, Puerto Deseado $47.75^{\circ} \mathrm{S}, 65.9^{\circ} \mathrm{W}$, intertidal depth, among Spartina sp., 1963.

Paratypes: (22) complete adults, 10-32 mm long, 2-4 mm wide for 49-80 chaetigers (MLPOi 2536-2). Same station, collector, and date as holotype.

Description: Body fusiform, short and stout, anterior region without shoulders, rounded in cross section, dorsally inflated, ventrally grooved (Fig. 1A, B). Pygidium simple lobe with anus terminal. Color yellowish in alcohol.

Prostomium conical, round, as long as two first chaetigers; with lateral oblique nuchal organs (Fig. 1C), and one oblique row of black eyespots (five-eight) almost continue (Fig. 1D), not observed under SEM. Peristomium with three annuli, as long as two-three chaetigers, first annulus distinctly separated from prostomium (Fig. 1A, B). Two oblique groups of four-six tentacular filaments, arising from chaetiger 1; first pair of branchial filaments from anterior part of chaetiger 1 (Fig. 1B). Branchiae a pair per chaetiger, less abundant in middle region and absent in last chaetigers. Branchial filaments arise close to notopodium in first chaetigers, at the same distance between noto- and neuropodium, then slightly more dorsal to on middle region of the body. The distance between branchial insertion in respect to notopodium is twice and a half the distance between noto- and neuropodium or more from the chaetiger 8 .

Noto- and neuropodium very close and with differentiation in chaetes; chaetigers with a simple row of capillaries in the notopodium (5-6) and in the neuropodium (3-4). Capillary chaetae with one edge with blade distinctly striated at base, and a serrated edge seen in optical microscope (100x) and SEM. Acicular spines slightly curved distally, present from middle chaetigers in notopodium (10-13), alternated with serrated capillaries; two-four neuropodial acicular spines from chaetiger 1 (Fig. 1E) intercalated by capillaries.

Methyl green staining pattern: No distinctive staining pattern. Whole worm stained with light green.

Habitat: Tidal flats inhabited by Spartina sp.

Reproduction: There is no available information about sexual or asexual reproduction for this species. However, specimens with eggs were observed in the coelomic cavity. (Fig. 1F).

Distribution: This species is only known for the locality of Puerto Deseado $\left(47.75^{\circ} \mathrm{S}\right.$ $65.9^{\circ} \mathrm{W}$ ) in intertidal areas of the SW Atlantic Ocean, Argentina.

Remarks: Cirratulus orensanzii n. sp. is similar to Cirratulus jucundus and Cirratulus patagonicus in the general body morphology, including the number and position of eyespots but differs in respect to the number of tentacular filaments: $C$. jucundus has eight- 10 and $C$. patagonicus 15-20 in each fascicle but Cirratulus orensanzii $\mathrm{n}$. sp. has four-six. In addition, 

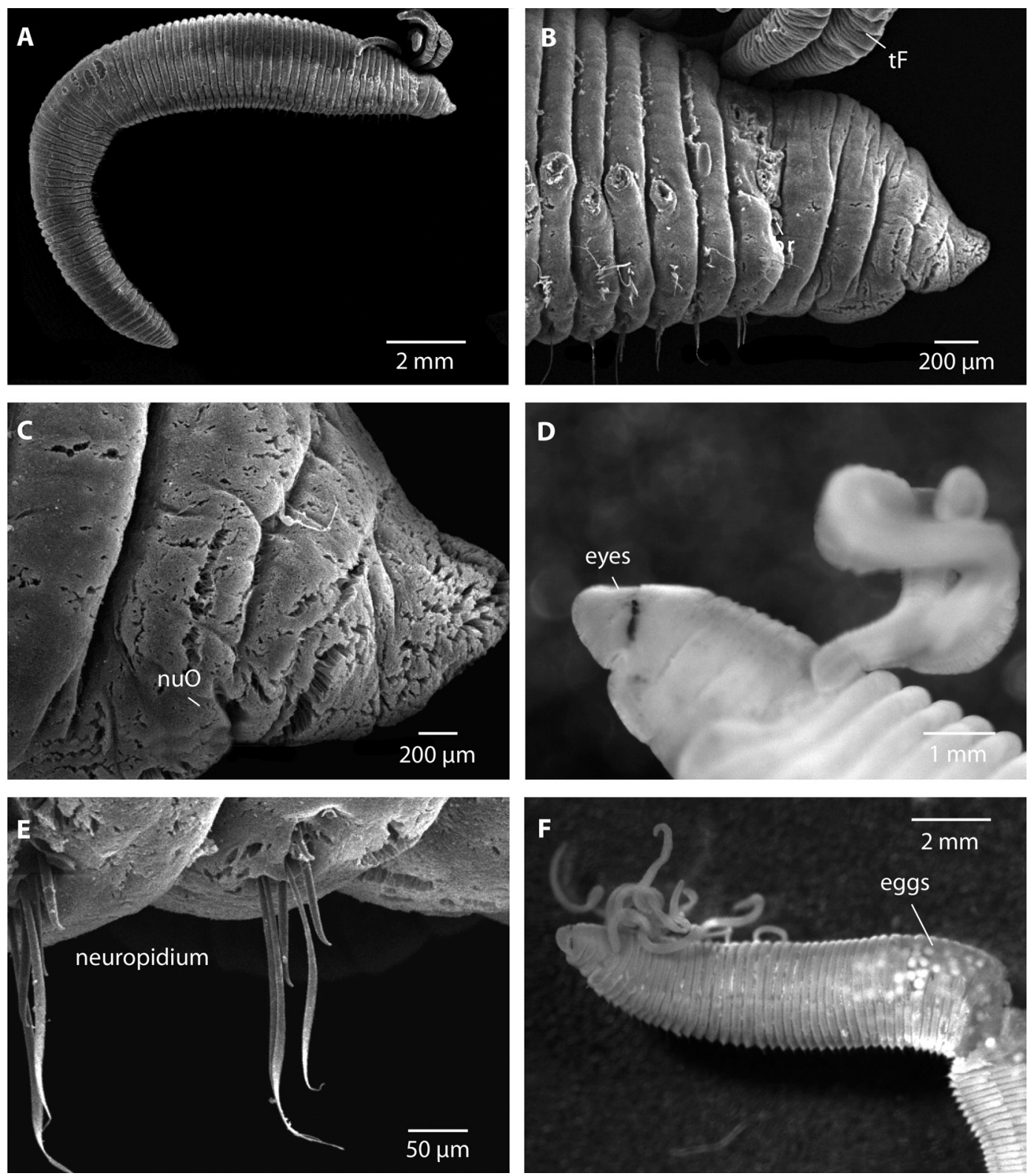

Fig. 1. Cirratulus orensanzii sp. nov. (A) Complete specimen in lateral view; (B) Anterior end in lateral view showing peristomium and origin of tentacular filaments (tF) and first branchiae (br); (C) Detail of nuchal organ; (D) Eyespots on the prostomium; (E) Pattern of capillaries and acicular spines in neuropodium; (F) Complete specimen showing eggs in the coelomic cavity. D and F, optical microscopy photo; A-C and E, SEM photograph.

the position of the first pair of branchiae is in the posterior end of the first chaetiger in both C. jucundus and C. patagonicus but in Cirratulus orensanzii n. sp., it is in the anterior end of the first chaetiger. The neuropodial spines appear from the first chaetiger, and the notopodial spines from chaetigers 6-9 in C. jucun$d u s$ whereas in Cirratulus orensanzii n. sp. neuropodial spines are from the first chaetiger and notopodial spines from middle chaetigers 
(10-13). The anus is terminal in C. jucundus, $C$. patagonicus, and Cirratulus orensanzii n. sp.

Other similar species is Cirratulus mianzanii with similar body morphology, however the first pair of branchial filaments in Cirratulus orensanzii $\mathrm{n}$. sp. arise from the anterior end of the first chaetiger below the tentacular filaments whereas in C. mianzanii they arise between the peristomium and the first chaetiger below the tentacular filaments. Neuropodial and notopodial spines start from the first chaetiger and middle chaetigers in both species, respectively. The pygidium has a ventral lobe and anus sub-terminal (dorsal) in C. mianzanii while it is terminal lacking lobes in Cirratulus orensanzii n. sp. The cross-section of these species also shows differences, mostly in respect to the position of branchiae throughout the body.

Ethymology: This species is dedicated to José María Orensanz (1945-2015) who was the father of the polychaetes of Argentina. He collected polychaetes from all the SW Atlantic, including a lot of the material described in this work.

\section{Cirratulus knipovichana n. sp. Saracho-Bottero \& Elías \\ (Fig. 2A-F; Fig. 4B)}

Type material: Holotype: complete adult, $23 \mathrm{~mm}$ long, $1.5 \mathrm{~mm}$ wide for 68 chaetigers (MLP-Oi 4186). SW Atlantic Ocean, Argentina, Sta. $250,34^{\circ} 51^{\prime}$ S, $52^{\circ} 35^{\prime}$ W, 83 m depth, coll. Dr. Jose María Orensanz.

Paratypes: (7) complete adults, 7-15 mm long, 1-1.5 mm wide for 50-80 chaetigers (MLP-Oi 4187), same station, collector, and date as holotype.

Additional material examined: (80) complete adults, 5-25 mm long, 1-1.5 mm wide for 48-80 chaetigers (MLP-Oi 4188), SW Atlantic Ocean, Argentina, Sta. 1055, 36 ${ }^{\circ} 16^{\prime}$ S, $54^{\circ} 01^{\prime}$ W, $92 \mathrm{~m}$ depth, coll. Dr. Jose Maria Orensanz. (55) complete adults, 5-25 mm long, 1-1.5 mm wide for 48-80 chaetigers (MLP-Oi
4189), SW Atlantic Ocean, Argentina, Sta. 1575, 3536' S, 5332' W, 68 m depth, coll. Dr. Jose Maria Orensanz.

Description: Body fusiform, short and stout, anterior region with first five-eight chaetigers crowded with incipient shoulders ventrally flat; then rounded in cross section, dorsally inflated, ventrally grooved (Fig. 2A, B). Pygidium simple lobe with anus terminal (Fig. 2A, F). Color brown-reddish in alcohol, with iridescent reflections.

Prostomium conical, round, as long as two first chaetigers; with lateral oblique nuchal organs (Fig. 2C), and one pair of black eyespots, not observed under SEM. Peristomium with three annuli, as long as three-four chaetigers, first annulus distinctly separated from prostomium (Fig. 2A, B). Two oblique groups of two-four tentacular filaments, arising from posterior end of peristomium and about the anterior end of first chaetiger (Fig. 2B). First pair of branchial filaments from posterior end of peristomium (Fig. 2D). Branchiae a pair per chaetiger, less abundant in middle region and absent in last chaetigers. Branchial filaments arise close to notopodium in first chaetigers, at same distance between noto- and neuropodium. Distance between branchial insertion in respect to the notopodium similar to distance between noto- and neuropodium.

Notopodium and neuropodium very close together; anterior and middle chaetigers with a single row of three-seven serrated capillary chaetae in notopodium, two-four serrated capillary chaetae in neuropodium, number of capillaries reducing towards posterior region. Capillary chaetae with one serrated edge (Fig. 2D). Acicular spines slightly curved distally, present from middle chaetigers in notopodium, alternated with serrated capillaries; two-four neuropodial acicular spines from chaetiger 1 (Fig. 3D) with one capillary chaeta between spines.

Methyl green staining pattern: No distinctive staining pattern. Whole worm stained with light green. 

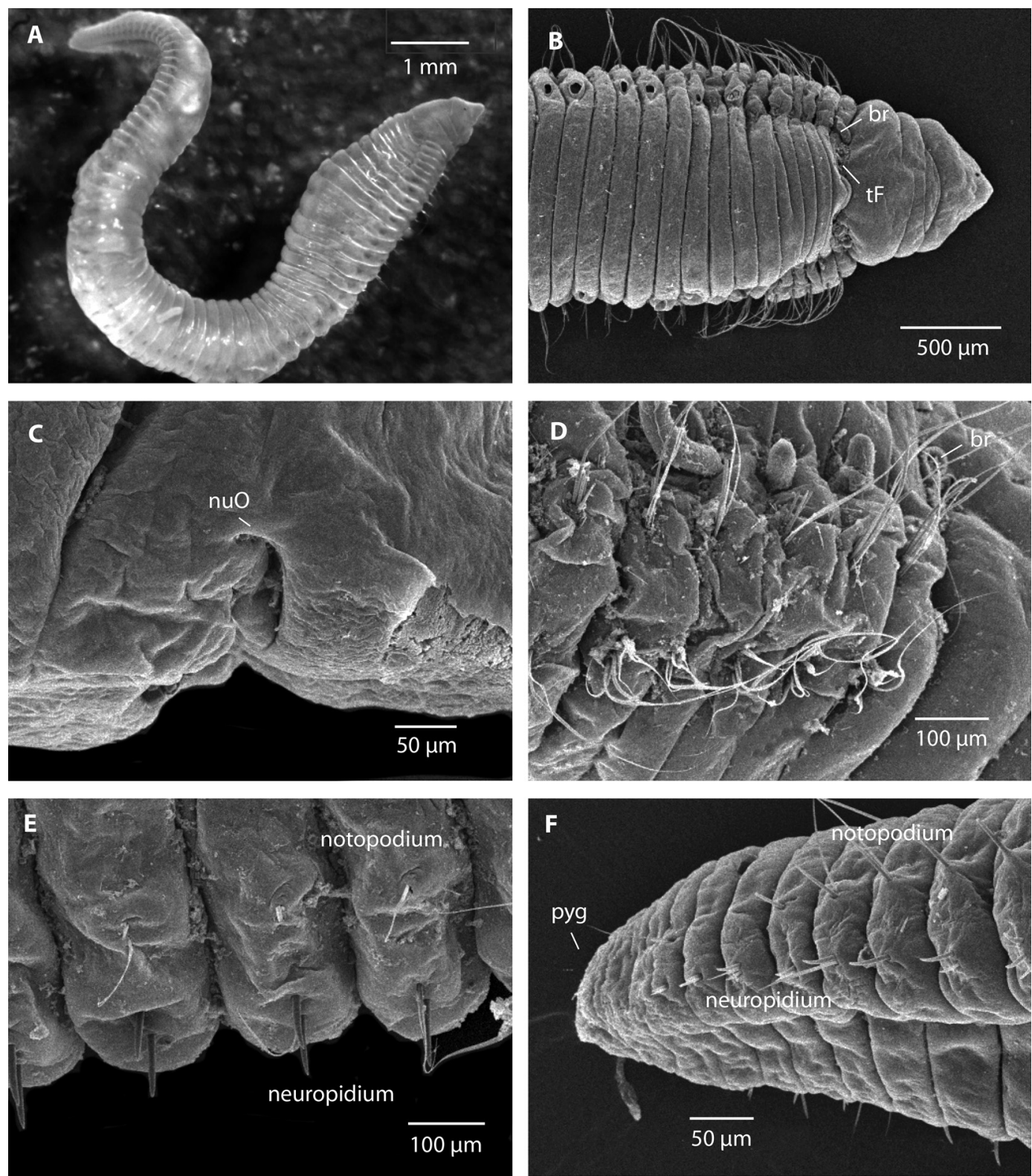

Fig. 2. Cirratulus knipovichana n. sp. (A) Complete specimen; (B) Anterior end in dorsal view showing peristomium and origin of tentacular filaments (tF) and first branchia (br); (C) Detail of nuchal organ; (D) Pattern of capillaries and acicular spines in noto- and neuropodium of anterior region; (E) Pattern of capillaries and acicular spines in noto- and neuropodium of middle region; (F) Pattern of capillaries and acicular spines in noto- and neuropodium of posterior region and pygidium (pyg). A, optical microscopy photo; C-F, SEM photograph. 
Habitat: Sand bottoms in subtidal depths.

Reproduction: There is no available information about sexual or asexual reproduction for this species.

Distribution: This species is distributed in the continental shelf off Argentina including the Rio de la Plata (SW Atlantic Ocean, Argentina).

Remarks: Cirratulus knipovichana n. sp. is similar to Cirratulus jucundus in the general body morphology, but differs in respect to the number of tentacular filaments: $C$. jucundus has eight-10 in each fascicle but two-four in C. knipovichana n. sp. In addition, the position of the first pair of branchiae is in the first chaetiger in C. jucundus, but in posterior end of peristomium in C. knipovichana $\mathrm{n}$. sp.; the neuropodial spines appear from the first chaetiger, and the notopodial spines from chaetigers 6-9 in C. jucundus, whereas in C. knipovichana $\mathbf{n}$. sp. neuropodial spines are from first chaetigers and notopodial spines from middle chaetigers.

Other similar species is Cirratulus patagonicus with similar body morphology; however, it has two groups of 15 or more tentacular filaments whereas C. knipovichana $\mathrm{n}$. $\mathrm{sp}$. has only two-four tentacular filaments. The first pair of branchial filament in C. knipovichana $\mathrm{n}$. sp. arises from the groove between the peristomium and chaetiger 1 below the tentacular filaments whereas in $C$. patagonicus they are from the posterior region of chaetiger 1. Neuropodial spines start from chaetiger 1 in Cirratulus patagonicus and notopodial spines from chaetigers 10-12, whereas neuropodial spines are from chaetigers 9-10 in C. knipovichana n. sp. and notopodial spines from chaetigers 21-24. The cross-section of these species also shows differences, mostly in respect to the position of branchiae throughout the body.

C. knipovichana n. sp. is similar to $C$. orensanzii n. sp. in having tentacular filaments and first pair of branchiae on the first chaetiger, but the number of tentacular filaments is low (two-four) in the first respect the later (four-six).

Ethymology: The species is dedicated in honor to "Akademik Knipovich", a Russian research vessel. A research fishery expedition in 1965-1966 to Antarctica and adjacent waters of the Southern Atlantic allowed Jose M. Orensanz collecting a lot of polychaetes, part of which was identified in this study.

\section{Cirratulus alfonsinae n. sp. Saracho-Bottero \& Elías (Fig. 3A-F; Fig. 4F)}

Type material: Holotype: complete adult, $10 \mathrm{~mm}$ long, $1 \mathrm{~mm}$ wide for 50 chaetigers (MLP-Oi 4190). Playa Grande, SW Atlantic Ocean, Argentina, Rocky shore, intertidal; coll. Dr. Jose Maria Orensanz. January 22, 1969.

Paratypes: (1) complete adult, $15 \mathrm{~mm}$ long, $1 \mathrm{~mm}$ wide for 55 chaetigers (MLP-Oi 4191). Same station, collector, and date as holotype.

Description: Body fusiform, short, first seven chaetigers with low shoulders, then become less obvious and disappear around chaetiger 11-12; rounded in cross section, dorsally inflated, ventrally flat (Fig. 3A, B). Pygidium with ventral lobe and anus dorsal and subterminal (Fig. 3A, F). Color white in alcohol.

Prostomium conical, flat, as long as two anterior chaetigers; with nuchal organs as lateral slits (Fig. 3C), without eyespots. Peristomium with two annuli (three annuli in paratype), as long as three chaetigers (Fig. 3A, B). Two oblique groups of 2-3 tentacular filaments arising from chaetiger 1 and the first pair of branchial filaments from groove between peristomium and chaetiger 1 (Fig. 3 A, B). A few thick and short branchiae in anterior chaetigers, arising close to notopodium always.

Noto- and neuropodium close together; anterior and middle chaetigers with a single row of three-seven serrated capillary chaetae in notopodium, two-four serrated capillary chaetae in neuropodium; number of capillaries reducing towards posterior region. Capillary 

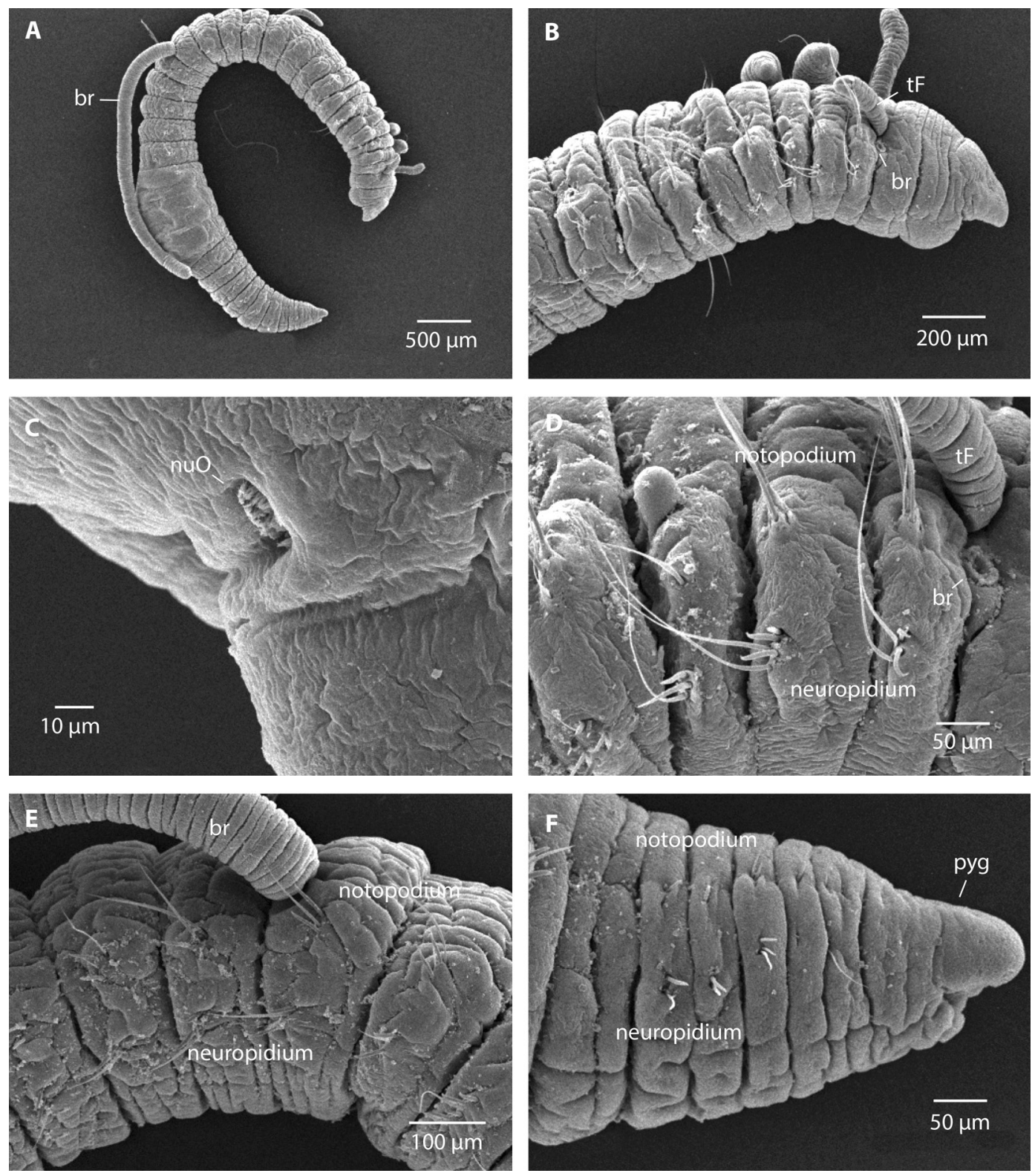

Fig. 3. Cirratulus alfonsinae n. sp. (A) Complete specimen; (B) Anterior end in lateral view showing peristomium and origin of tentacular filaments (tF) and first branchia (br); (C) Nuchal organ; (D) Pattern of capillaries and acicular spines in noto- and neuropodium of anterior region; (E) Pattern of capillaries and acicular spines in noto- and neuropodium of middle region; (F) Pattern of capillaries and acicular spines in noto- and neuropodium of posterior region and pygidium (pyg). A-F, SEM photograph.

chaetae with one edge with blade distinctly striated at the base, and a serrate edge seen in optical microscope (100x) and SEM. Acicular spines slightly curved distally from chaetiger
12-16 in in notopodium, alternated with serrated capillaries; neuropodial acicular spines from chaetiger 7 (Fig. 3 D) also alternated with serrate capillaries and present throughout. 
A

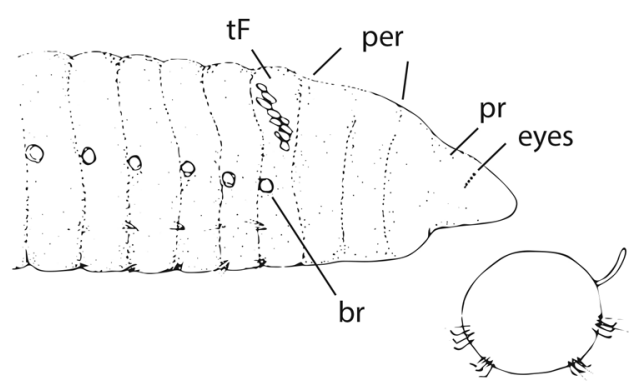

B

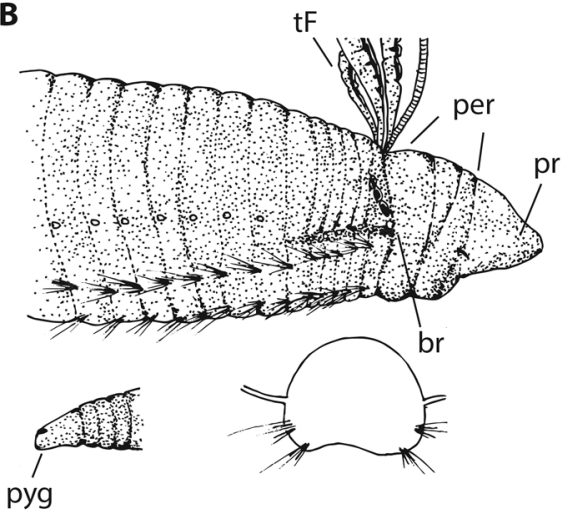

c
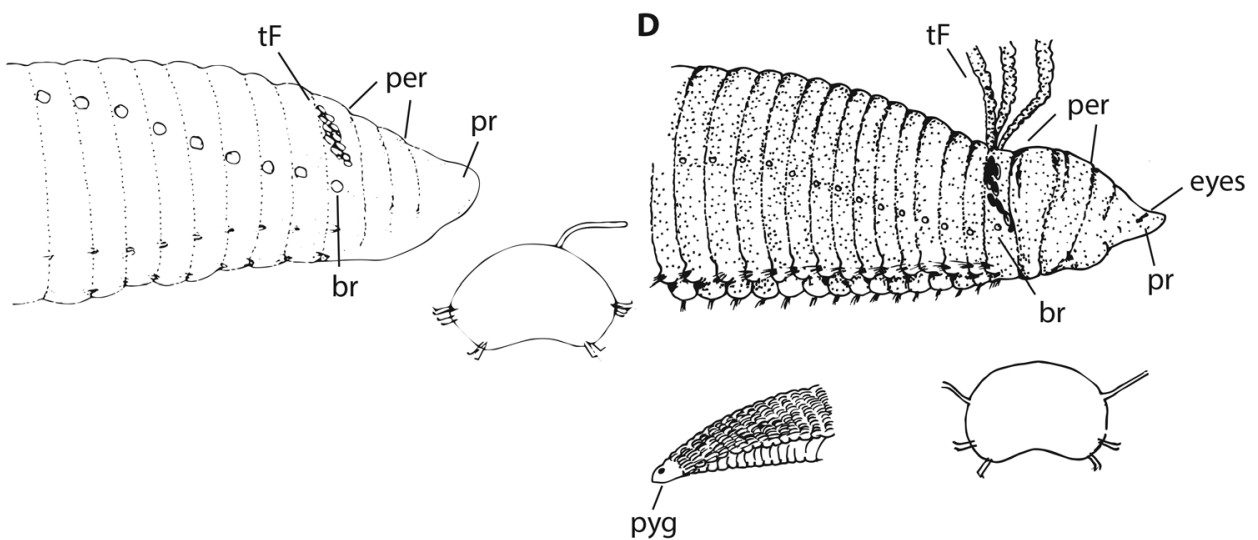

$\mathbf{E}$

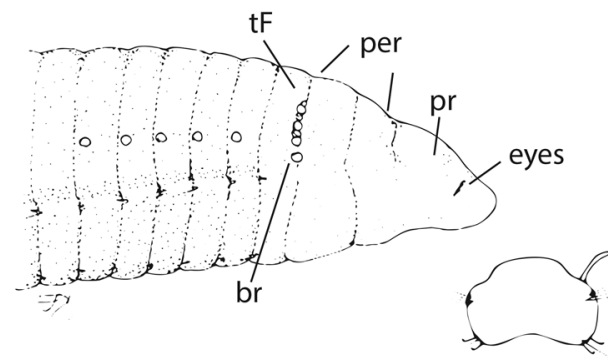

$\mathbf{F}$
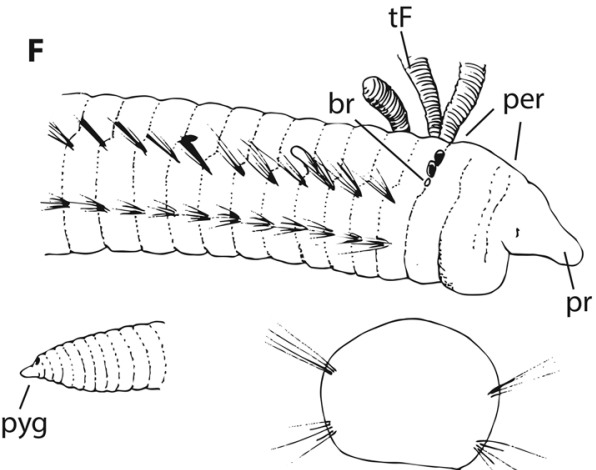

Fig. 4. Key to Cirratulus of Argentine waters (A) Cirratulus jucundus (B) Cirratulus knipovichana n. sp. (C) Cirratulus patagonicus (D) Cirratulus orensanzii n. sp. (E) Cirratulus mianzanii (F) Cirratulus alfonsinae n. sp. 
Methyl green staining pattern: No distinctive staining pattern. Whole worm stained with light green.

Habitat: Rocky shore, intertidal.

Reproduction: There is no available information about sexual or asexual reproduction for this species.

Distribution: This species is only known for the locality of Mar del Plata in intertidal areas of the SW Atlantic Ocean, Argentina.

Remarks: Cirratulus alfonsinae n. sp. is similar to the rest of the species of Cirratulus of Argentina, but differs in respect to the segmental origin of the branchiae. In C. alfonsinae n. sp. the branchiae arise from near notopodial base throughout the body.

Cirratulus alfonsinae $\mathrm{n}$. $\mathrm{sp}$. is similar to Cirratulus jucundus in the general body morphology, but differs in respect to the number of tentacular filaments: C. jucundus has eight-10 in each fascicle but 2-3 in C. alfonsinae n. sp. In addition, the position of the first pair of branchiae is in the first chaetiger in C. jucundus, but in the posterior end of peristomium in C. alfonsinae n. sp.; the neuropodial spines appear from the first chaetiger, and the notopodial spines from chaetigers 6-9 in C. jucundus, whereas in $C$. alfonsinae $\mathrm{n}$. sp. neuropodial spines are from chaetigers 7 and notopodial spines from chaetigers 12-16.

Other similar species is Cirratulus patagonicus with similar body morphology, however it has two groups of 15 or more tentacular filaments whereas C. alfonsinae n. sp. has only
2-3 tentacular filaments. The first pair of branchial filaments in $C$. alfonsinae n. sp. arise from the groove in between the peristomium and first chaetiger below the tentacular filaments whereas in $C$. patagonicus they are from the posterior region of chaetiger 1 . Neuropodial spines start from chaetiger 1 in Cirratulus patagonicus and notopodial spines from chaetigers 10-12, whereas neuropodial spines are from chaetigers 7 in C. alfonsinae n. sp. and notopodial spines from chaetigers 12-16. The crosssection of these species also shows differences, mostly in respect to the position of branchiae throughout the body.

C. alfonsinae n. sp. is similar to C. orensanzii n. sp. in the general body morphology, but differs in the number of tentacular filaments; it is low (two-three) in the first respect the later (four-six) and $C$. alfonsinae n. sp. lacks eyespots.

Additional useful characters could be related to the ultrastructure of the capillary chaetae and organization of the eyespots $(C$. orensanzii n. sp. (five-eight); C. knipovichana n. sp. (with one or without) and C. alfonsinae n. sp. (without)).

Ethymology: The species is dedicated to Alfonsina Storni (1892-1938). She was a teacher and was a poet, and her prose was feminist. Critics attribute an originality that changed the meaning of Latin American lyrics. She had breast cancer and chose suicide. She threw herself from the breakwater of the Club Argentino de Mujeres, from the city of Mar del Plata, although a song dedicated in her honor portrayed her slowly entering the sea.

\section{Key to Cirratulus of Argentine waters}

Branchiae arising from near notopodial base throughout the body and anterior chaetigers with shoulders, ventrally flat,

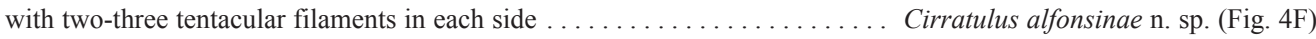
Branchiae arising from near notopodial base in anterior chaetigers but can be migrate to different distance from noto-

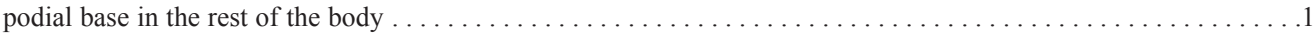

1a. Branchial filaments from chaetiger 1 arising in dorsal region of notopodial base, becoming dorsal throughout the body

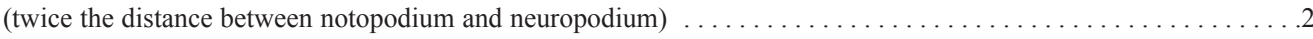

1b. Branchial filaments from chaetiger 1 arising in dorsal region of notopodial base, becoming more dorsal throughout the

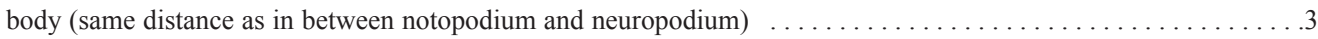


2a. 15-20 tentacular filaments and branchial filaments increasingly separated from the notopodium reaching the dorsum from chaetiger $10-12 \ldots \ldots \ldots \ldots \ldots \ldots \ldots \ldots \ldots \ldots \ldots \ldots \ldots \ldots \ldots \ldots \ldots \ldots \ldots \ldots \ldots$ Cirratulus patagonicus $($ Fig. 4 C)

2b. Four-six tentacular filaments and branchial filaments increasingly separated from the notopodium until chaetiger

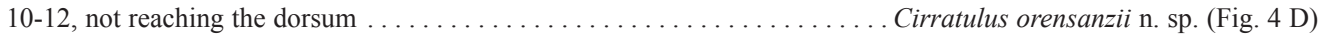

3a. With one pair or without eyespots and having two-four tentacular filaments, first chaetigers crowded, with shoulders Cirratulus knipovichana n. sp. (Fig. 4 B)

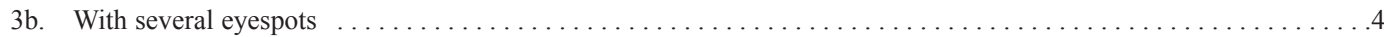

4a. Eight-10 tentacular filaments and first branchial filaments appearance from posterior end of chaetiger 1 . Cirratulus jucundus (Fig. 4 A)

4b. Four-five tentacular filaments and first branchial filaments from peristomium and chaetiger1 ... Cirratulus mianzanii (Fig. 4 E)

\section{DISCUSSION}

The diversity of cirratulids in Argentina is increasing as the studies of this family are deepened. A first step occurred when the studies focused on the bitentaculate species (Elias \& Rivero, 2008), and now occurs in the multitentaculate species. This trend is expected to be similar in other areas of the southern hemisphere.

Table 1 was realized to bring together the morphology and distributional records of 10 accepted species of Cirratulus in Atlantic Ocean waters in order to assist non-specialists with the identification of specimens. It is noteworthy, that Cirratulus cirratus, the type species, is included in this table because it is one of the most conflicting species within the genus both for its taxonomy and its wide distribution. This distribution is probably due to wrong identifications.

This study was favored by two reasons, one reviewing the material deposited in the two largest natural science museums of Argentina, and the other by the review of the material collected by Lobo Orensanz throughout his life (1945-2015). This collection was lost for several years, but it was found among the belongings of our remembered Mary E. Petersen (1938-2014), and shipped back to Argentina.
In a relatively little time we have described four new Cirratulus species, that added to the two previously described species. In the annotated catalogue of J. M. Orensanz (unpublished) he mentioned the two species described by Kinberg (1866) for Antarctica, C. patagonicus, C. jucundus, and a Cirratulus near cirratus species. The latter is most probably a misidentification rather than an enlargement of the distribution of this European species. Probably, more additions will rise when deepen studies reveal the real diversity of Cirratulids in austral waters. Argentina has more than 4500 $\mathrm{km}$ of costal lines, mostly unexplored. The continental shelf, extending more than $350 \mathrm{~km}$ offshore in some austral regions, is also poorly known, perhaps the new initiative of Argentine government, the Pampa Azul project (Comité Coordinador Interministerial, 2019), intending to explore the submarine areas, allows knowing more about the polychaetes and in particular about Cirratulids.

Ethical statement: authors declare that they all agree with this publication and made significant contributions; that there is no conflict of interest of any kind; and that we followed all pertinent ethical and legal procedures and requirements. All financial sources are fully and clearly stated in the acknowledgements 


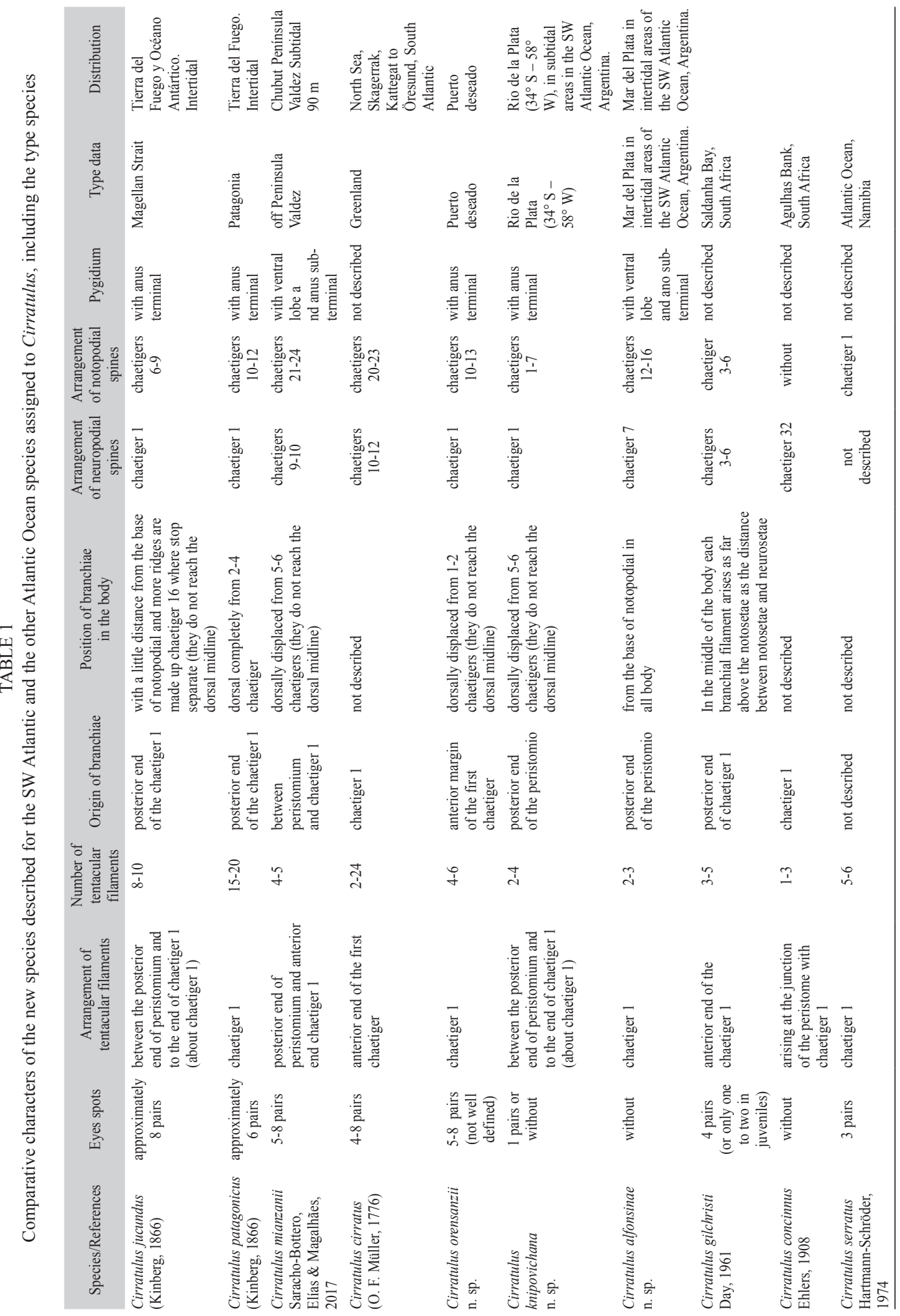


section. A signed document has been filed in the journal archives.

\section{ACKNOWLEDGMENTS}

To Mora Orensanz and Ana Parma for the management to get the collection of $\mathrm{J}$. M. Orensanz. SEM images were obtained by Monica Oppedisano from the Laboratorio de Microscopía Electrónica de la Facultad de Ciencias Exactas y Naturales de la Universidad Nacional de Mar del Plata. This study was supported by the "Systematics and Taxonomy of Austral Cirratulidae (Polychaeta)" grant project PICT $2013 \mathrm{~N}^{\circ} 1511$ of Agencia Nacional de Promoción de Ciencia y Técnica.

\section{RESUMEN}

\begin{abstract}
Revisión de Cirratulus (Cirratulidae: Polychaeta) de Argentina, con la descripción de tres nuevas especies y una clave para identificar todas las especies del área
\end{abstract}

Introducción: La taxonomía de Cirratulidae no es fácil debido a que los caracteres diagnósticos actualmente aceptados cambian a través de la ontogenia; en algunos casos, incluso existen dificultades para separar a los juveniles de los adultos. Entre las especies de Cirratulus citadas, descritas y consideradas como válidas para Argentina se encuentran Cirratulus jucundus (Kinberg, 1866), Cirratulus patagonicus (Kinberg, 1866) y Cirratulus mianzanii Saracho Bottero, Elias \& Magalhães, 2017. Objetivo: El presente estudio hace una revisión de Cirratulus que incluye material depositado en el Museo de Ciencias Naturales de La Plata (MLP) y especímenes recolectados en privado por JM Orensanz que fue donado al laboratorio de Bioindicadores Bentónicos de la Universidad Nacional de Mar del Plata. Métodos:Las muestras se examinaron con equipo óptico (microscopio y estereomicroscopio) y también con microscopio electrónico de barrido (SEM). Resultados: Un examen completo del material, reveló un mayor número de especies que las ya mencionadas. En el presente trabajo, se describen tres nuevas especies de las áreas intermareales y submareales de la plataforma continental argentina: Cirratulus orensanzii n. sp.; Cirratulus knipovichana $\mathrm{n}$. sp. y Cirratulus alfonsinae n. sp. Conclusiones: El conocimiento sobre la taxonomía de la familia, así como la actualización de los registros geográficos, contribuye a la biodiversidad de la región, lo cual es de gran importancia para llevar a cabo estudios ecológicos y planes de conservación.
Palabras clave: Cirratulus, distribución geográfica, taxonomía, nuevo registro

\section{REFERENCES}

Blake, J. A. (1996). Family Cirratulidae Ryckholdt, 1851. Including a revision of the genera and species from the Eastern North Pacific. In J.A. Blake, B. Hilbig and P.H. Scott (Eds.) Taxonomic atlas of the benthic fauna of the Santa Maria Basin and western Santa Barbara Channel, Volume 6. The Annelida, Part 3 (pp. 347-358). Santa Barbara, California, USA: Santa Barbara Museum of Natural History.

Blake, J. A. \& Magalhães, W. (2017). Family Cirratulidae Ryckholt, 1851. In W. Westheide, \& G. Purschke, (Eds.). Handbook of Zoology Online, a Natural History of the Phyla of the Animal Kingdom-Annelida, Polychaetes. Berlin, Germany: De Gruyter.

Cinar, M. E., \& Petersen, M. E. (2011). Re-description of Cirratulus dollfusi (Polychaeta: Cirratulidae), and Fauvelicirratulus as a new genus. Journal of the Marine Biological Association of the United Kingdom, 91(2), 415-418

Czerniavsky, V. (1881). Materialia ad zoographiam Ponticam comparatam. Fasc. III Vermes [Second part]. Byulleten' Moskovskogo obshchestva ispytatelei prirody, 56(2), 338-420

Day, J. H. (1961). The Polychaet [sic] Fauna of South Africa. Part 6. Sedentary species dredged off Cape coasts with a few new records from the shore. Journal of the Linnean Society of London, 44(299), 463-560.

Ehlers, E. (1908). Die bodensässigen Anneliden aus den Sammlungen der deutschen Tiefsee-Expedition. In C. Chun (Ed.). Wissenschaftliche Ergebnisse der Deutschen Tiefsee-Expedition auf dem Dampfer ''Valdivia' 1898-1899 (pp. 1-168, Vol. 16). Jena, Germany: Verlag Von Gustav Fischer.

Elias, R., \& Rivero, M. S. (2008). Two new species of Caulleriella (Polychaeta, Cirratulidae) from Argentina. Iheringia Serie Zoologia, 98(2), 225-230.

Comité Coordinador Interministerial. (2019). Pampa Azul. Recuperado de http://www.pampazul.gob.ar

Hartman, O. (1936). Nomenclatural changes involving California polychaete worms. Journal of the Washington Academy of Sciences, 26(1), 31-32.

Hartmann-Schröder, G. (1974). Zur Kenntnis des Eulitorals der afrikanischen Westküste zwischen Angola und Kap der Guten Hoffnung und der afrikanischen Ostküste von Südafrika und Mocambique unter besonderer Berücksichtigung der Polychaeten und Ostracoden. Teil II. Die Polychaeten des Untersuchungsgebietes. Mitteilungen des Hamburgischen 
Zoologischen Museums und Instituts. Ergänzungsband zu Band, 69, 95-228.

Kinberg, J. G. H. (1866). Annulata nova. Öfversigt af Königlich Vetenskapsakademiens förhandlingar, 23(9), 253-255.

Lamarck, J. B. (1818). Histoire naturelle des Animaux sans Vertèbres, préséntant les caractères généraux et particuliers de ces animaux, leur distribution, leurs classes, leurs familles, leurs genres, et la citation des principales espèces qui s'y rapportent; précédée d'une Introduction offrant la Détermination des caractères essentiels de l'Animal, sa distinction du végétal et des autres corps naturels, enfin, l'Exposition des Principes fondamentaux de la Zoologie. Volume 5. Paris, France: Déterville \& Verdière.
Müller, O. F. (1776). Zoologiae Danicae prodromus: seu Animalium Daniae et Norvegiae indigenarum characteres, nomina, et synonyma imprimis popularium. Hafniae [Copenhagen], Denmark: Typiis Hallageriis.

Ryckholt B. P. (1851). Mélanges Paléontologiques, part 1. Mémoires Courronnés et Mémoires des Savants Étrangers de l'Académie Royale des Sciences, des Lettres st des Beaux-Arts de Belgique, 24, 1-176.

Saracho Bottero, M. A., Magalhães, W., \& Elías, R. (2017). Taxonomic revision of Cirratulus (Polychaeta: Cirratulidae) from the coasts of Argentina, with description of a new species. Journal of the Marine Biological Association of the United Kingdom, 97(5), 889-896. 